\title{
Environment education and sustainable development initiatives in Jamaica
}

\author{
Santosh Kumar Mishra \\ Department of Continuing and Adult Education and Extension Work, S. N. D. T. Women's University, Maharashtra, India \\ Email address: \\ drskmishrain@yahoo.com \\ To cite this article: \\ Santosh Kumar Mishra. Environment Education and Sustainable Development Initiatives in Jamaica. Journal of Energy and Natural \\ Resources. Vol. 2, No. 6, 2013, pp. 41-55. doi: 10.11648/j.jenr.20130206.11
}

\begin{abstract}
Education for sustainable development (ESD) is a concept that goes far beyond environmental education. It is the educational process of achieving human development (which envisages three pillars of human development: "economic growth", "social development", and "environmental protection") in an inclusive, equitable and secure manner. It, thus, includes education for: poverty alleviation, human rights, gender equality, cultural diversity, international understanding, peace, etc. The concept of putting environmentally sustainable development into practice involves challenges that are as diverse as the make-up of population. Sustainable development ultimately depends on enhancing people's capacities as individuals and groups to improve their own lives and to take greater control over their own destinies. Education is contended to be a critical tool for achieving sustainable development. The major environmental problems in Jamaica involve water quality and waste disposal. Further, about 680 plant species are also threatened. Endangered species in Jamaica include the tundra peregrine falcon, swallowtail butterfly, green sea turtle, hawksbill turtle, and American crocodile. This paper proposes a framework for conceptualizing, planning for and implementing an education agenda for sustainable development within the Jamaican context. The paper concludes that Jamaica will continue to achieve its goals in adopting the right approach for the ongoing interdependence of the environment and the economy in the 21st century and beyond. The Jamaican Government seeks to stimulate "economic re-growth" and stimulate the minds of people to create an interest in exploring solutions to environmental issues.
\end{abstract}

Keywords: Education for Sustainable Development, Environment, Initiatives, Jamaica, Endangered Species, Framework, Strategic Issues

\section{Introduction}

The major environmental problems in Jamaica involve water quality and waste disposal. Further, about 680 plant species are also threatened. Endangered species in Jamaica include the tundra peregrine falcon, homerus swallowtail butterfly, green sea turtle, hawksbill turtle, and American crocodile. Thus, the educational implications of sustainable development within the Jamaican context require special attention. The National Environmental Education Action Plan for Sustainable Development is guided by a vision of a future for Jamaica in which social, economic and environmental components of sustainability are harmonized. The key element in bringing this vision to reality is through education [(National Environmental Education Committee (NEEC), 2010].

This paper proposes a framework for conceptualizing, planning for and implementing an education agenda for sustainable development within the Jamaican context. The strategic questions informing this framework are:

- What is the context within which sustainable development is being proposed? What are the educational needs that arise within the given context?

- What mechanism would best facilitate these needs thus satisfying the sustainable development objectives?

The central thesis of the paper is that sustainable development ultimately depends on enhancing people's capacities as individuals and groups to improve their own lives and to take greater control over their own destinies. The educational implications of sustainable development within the Jamaican context are therefore assessed.

\section{Methodology}


This paper proposes a framework for conceptualizing, planning for and implementing an education agenda for sustainable development within the Jamaican context. It also discusses some initiatives taken in Jamaica in order to achieve the goal of sustainable development. In view of these objectives, data from various secondary sources have been collected. The data are primarily descriptive in nature. Selected projects on environment and sustainable development undertaken by various developmental partners (both in governmental and non-governmental sectors) have been emphasized upon.

\section{Conceptual Framework of Sustainable Development}

Sustainable development promotes a development approach that is holistic in nature and rejects a survivalist tendency which speaks to survival at all cost. In the year 1987, the World Commission on Environment and Development (WCED, otherwise known as "the Brundtland Commission") suggested following definition of sustainable development:

"economic and social development that meets the needs of the current generation without compromising the ability of future generations to meet their own needs".

"Meeting the needs of the present" means satisfying:

- Economic needs - including:

$\circ$ an adequate livelihood or productive economic activity; and

o economic security when unemployed, ill, disabled or otherwise unable to secure a livelihood.

- Social, cultural and health needs - including a shelter which is:

o healthy, safe, affordable; and

o secure, with provision for piped water, drainage, transport, health care, education and child development and protection from environmental hazards.

- Political needs - including freedom to participate in national and local politics and in decisions regarding management and development of one's home and neighbourhood within a broader framework which ensures:

$\circ$ respect for civil and political rights; and

$\circ$ the implementation of environmental legislation.

The interpretation of "without compromising the ability of future generations to meet their own needs" include:

- monitoring use or waste of non-renewable resources; and

- sustainable use of renewable resources (including using freshwater, soils and forests) in ways that ensure a natural rate of recharge and keeping within the natural capacity of the environment to absorb human generated waste

\section{Contextualizing Sustainable Development in Jamaica}

Jamaica was one of the countries that signed the Agenda 21 agreement at the 1992 Earth summit in Rio de Janeiro. The agreement called for a global partnership for sustainable development. Through this agreement Jamaica, like many other countries, committed itself to promote sustainability through a great variety of activities. But, as with many other Latin American and Caribbean countries, Jamaica (since 1977) was forced to undertake: (a) structural reforms to stabilize its economy, and (b) sustainable development initiatives (Barrett, Shermaine 2006).

Structural adjustment has been most traumatic for Jamaica. The Government has divested many of the public operations, e.g., electricity, transportation. The cost of accessing health care and a good education has risen. Many Government agencies are now Executive Agencies meaning among other things they must earn their keep. These former government agencies that got their yearly budget from the central budget no longer enjoy that benefit rather they must begin to develop new strategies to provide the public with efficient and cost effective service. This often means an increase or introduction of user fees for many social services. In the meantime, the private sector struggles with liquidity and there are numerous accounts of businesses collapsing, others strategically choosing to:

a) scale back operations through restructuring, downsizing, layoffs and redundancies; and

b) leaving many without employment.

The adverse macroeconomic environment and the attendant policies adopted to overcome the economic problems facing the country have put pressure on the taxpayer's ability to foot the bill for the delivery of various social services including education and health (Knowledge Management Branch of DPADM/UNDESA, June, 2003). The results of the structural adjustment program are clear and include:

- high unemployment and reduced standard of living for many,

- the exacerbation of poverty and inequality,

- a net outflow of wealth from the country,

- social unrest, and

- $\quad$ increased incidents of crime and violence.

Within this context the United Nations Development Program, the Jamaica Human Development Report (2000) identified a number of issues related to vulnerability and human insecurity in Jamaica. These issues include:

- poverty evidenced by dilapidated house,

- no sanitary convenience,

- inability to care for children,

- hunger,

- no job or steady income,

- violence, and

- crime. 
The resulting adverse situation, as mentioned above, severely affected community spirit and social relations. It was due to:

- fear;

- distrust;

- interpersonal conflicts;

- destruction of community infrastructure and political tribalism; and

- inadequate housing/shelter, land tenure and social amenities impacted by low income of households.

The above situation ultimately led to:

- absence of:

$\circ$ protection,

$\circ$ access to services and amenities,

○ privacy,

access to jobs,

$\circ$ income, and

$\circ$ recreation and socialization.

- inadequate food, nutrition and health resulting in:

$\circ$ low weight for age,

$\circ$ anemia among young children, and

o pregnant and lactating women.

- nutrition related chronic diseases such as:

o diabetes,

o hypertension,

$\circ$ cardiac diseases, and

o stroke.

- environmental threats mainly related to:

o water and air quality,

o improper waste disposal, and

o natural disasters and environmental accidents.

The report states that "the factors outlined impoverish the lives and directly or indirectly threaten the economic, physical, and emotional/psychological well being of a large number of persons in Jamaica". In other words, for the Jamaicans their own sustainability is under threat and so despite a context of structural reform, the government must intervene to steer development towards sustainability for all and any program of sustainable development must address those social, economic and environmental issues present in local context.

On the positive side is the emergence of some important developments that provide a sound base for the participatory education program. The first development is a process of:

- decentralization,

- replacing the traditional centralized,

- bureaucratic decision-making, and

- governance approach inherited from colonialism.

Decentralization unlike centralization is based on the premise of inclusion. Participation and consensus building and legitimate instruments of democracy are given greater relevance or importance in a context of decentralization. The notion of "rulership with the people" rather than "rulership of the people" gets prominence. In
Jamaica, decentralization include the restructuring and strengthening of local government and the establishment of parish development committees - bodies at the parish level made up of representatives from the various communities within the parish. According to the Social Development Commission (1998), these committees provide a mechanism for coordinating the planning, implementing and monitoring process at the parish level (End Decade Assessment of World Summit for Children Goals, November, 2010).

The other development is the resurgence in the type and number of civil society groups around neighbourhood security, social services, human rights and justice, environmental protection, governance and free and fair elections, providing opportunity for the voice of the people to be heard in a clear organized manner. This emergence paves the way for a more cohesive society and again indicates a deepening of the democratic functioning of the society (United Nations Publication, 2007).

\section{The Jamaican Framework}

A program of education for sustainable development must address the social economic and environmental issues relevant to its context. This speaks to education that is appropriate and relevant. Here, the pertinent question needing answer is: What does this mean for Jamaica? It means sustainable development education in Jamaica must contend with the challenges of:

a) poverty and inequality,

b) debt,

c) ill-health,

d) poor nutrition, and

e) environmental degradation.

It must play the central role in establishing cohesion and harmony within the local context of mistrust, social unrest, violence and aggression. It must bring people together in creative collaboration and cooperation to assist in breaking down ethnic, economic, class, gender and political barriers that cause people to feel alienated. It must respond to the challenges that threaten the disintegration of the Jamaican society through greed, insecurity and a lack of will to contribute to or protect the common good. It must involve learning the knowledge, skills, perspectives and values that will guide and motivate people to:

a) lead sustainable livelihoods,

b) participate in a democratic society, and

c) live in a sustainable manner.

However, meeting the capacity needs of individuals and groups to respond to the demands of the Jamaican environment cannot be accomplished through the traditional educational system with its narrow instrumental focus. It requires the involvement of more than the traditional players such as the Ministry of Education, Youth 
and Culture, teachers and other educational personnel (UNSESCO, October, 2006). The need exists for greater participation from partners such as:

- families;

- communities;

- private sector;

- government (local and central);

- non-governmental organizations (NGOs);

- informal education sector;

- media group (television, radio and newspaper);

- non-formal sector;

- public health educators;

- agricultural extension agents, and

- others in planning and implementing the education.

It cannot be expected the formal education system which in reality touches the children for a fraction of their lives to teach people everything about living, working and governing in a manner that will achieve sustainability for their community and nation. The plea is being made for a participatory approach which includes national, civil society and private sector actors in the design, implementation and monitoring of sustainable development activities and in particular, education.

\section{Role of Natural Resources Conservation Authority (NRCA)}

The Natural Resources Conservation Authority (NRCA), under the NRCA Act of 1991, is mandated to promote public awareness of the ecological systems of Jamaica and their importance to the social and economic life of the island. In an attempt to coordinate the ongoing efforts, and find creative and innovative new strategies for fulfilling this mandate, and in recognition of the fact that national problems require genuine partnerships for resolution, the NRCA spearheaded the formation of the National Environmental Education Committee (NEEC) in 1993(NEEC, 2010). This multi-stakeholder group, bringing together educators, environmentalists, community and private sector interest groups, consumer advocates as well as international agencies, undertook the development and implementation of activities to review, rationalize and harmonize ongoing activities. The NEEC initially sought to rationalize and harmonize roles, relationships and functions of the main players involved in environmental education at all levels.

In 1996, with the commencement of the Government of Jamaica/Canadian International Development Agency Environmental Action Program, the NEEC commenced work on a National Environmental Education Action Plan for Sustainable Development (NEEAPSD). The commitment of the various partner organizations and the dedication of the individual who have worked on the plan are commendable.

This important national initiative is Jamaica's National Master Plan which provides a framework for the achievement of Environmental Literacy in the early decades of the $21^{\text {st }}$ century. It was developed through a process of participation and consensus building involving a wide range of stakeholders and is guided by a vision of Jamaica in the $21^{\text {st }}$ century in which social, environmental and economic development are in balance and simultaneously pursued.

The plan is the National Framework Document, and seeks to harmonize Environmental Education action towards measurable results related to Jamaican citizens in a sustainable future. Its implementation is even more critical than its development and its success depends upon longterm support from:

- the Government,

- the public sector,

- all elements of the civil society, and

$0 \quad$ the private sector.

The NEEC and the NRCA are committed to the facilitation of the process. Underlying the strategies employed will be the long-term institutionalization for Environmental Education for Sustainable Development. Mobilization for implementation requires collective energy and long-term commitments. Opportunities must be sought, where synergies exist, to enrich existing and new education programs. An NEEC Secretariat housed within the NRCA will remain the lead agency in the implementation of the Action Plan and will work with Lead Agency Focal Points with key sectors to mobilize support for:

- project identification,

- prioritization,

$\circ$ development, and

○ implementation.

A parallel process of awareness-raising and advocacy will be undertaken by the Secretariat and the Lead Agency Focal Point on the National Environmental Education Action Plan for Sustainable Development. The National Environmental Education Committee, through its governing body, will develop and implement a performance review framework to monitor the progress of the plan (Economic Commission for Europe, Committee on Environmental Policy, October, 2013).

\section{Priority Themes}

The themes for Environmental Education for Sustainable Development reflect the reality of a mountainous island nation, famed for the beauty and variety enclosed within an area of just 4,411 square miles (10,991 square kilometers), where natural resource degradation and the demands of development are undermining the once proud claim: Land of Wood \& Water. Migration from rural poverty in search of a better life has spawned urban blight. The educational system is inadequate and there are not enough jobs, particularly not for the unskilled mass of the population. The resulting social ills are legion, and easily compounded. The internal situation is also affected by inescapable interactions with the world which laps at every inch of the 
coastline, wafts in on every breath of air, travels in and out on planes and ships, presses at the airwaves and penetrates every mode of communication (NEEC, 2010).

The constant interaction of the social, economic and natural environments, makes vital the context of sustainable development, and creates the subject matter of Environmental Education for Sustainable Development. The Jamaica National Environmental Action Plan (JANEAP), a guiding policy document for the definition of environmental and sustainable development priorities, states in its inception document: The GOJ has made proper environmental planning and protection a national priority, and will seek multiple avenues to ensure sustainable development; including:

- using economic tools and incentives to encourage the efficient use of natural resources;

- working with the private sector and NGOs in environmental management and protection;

- looking to strategic use of external sources of financing and investment for meeting critical needs on the road to sustainable development; and

- looking to population control as a means of reducing the pressure on the natural resource base, some of which is non-renewable."

The following list of immediate priorities, which incorporates information listed in JANEAP, provides a brief overview of the scope of environmental and sustainable development issues to be conveyed through Environmental Education for Sustainable Development programmes in Jamaica. The list starts with the integrative theme of sustainable development itself, and then explores, in their turn, issues related to the social, environmental and economic spheres and to practices which will produce the desired results:

- Sustainable Development: Sustainable Development is an overarching concept, relating to the harmonization of social, environmental and economic considerations in the cause of long-term human development. At the national level, sustainability can be linked to familiar socioenvironmental-economic themes such as energy conservation and solid waste management, already the basis of specific agency concerns; to the effects of pollution on individuals and communities through respiratory and other ailments; to more strictly ecological themes such as watersheds, biodiversity loss and marine resources; and to issues of equity and justice. For the broad mass of Jamaicans to join in a campaign for a sustainable future, there has to be a sense that all will benefit from actions taken and efforts made.

- Sustainable Development Planning: Sustainable Development Planning is an approach which takes account of people's needs, rights and economic opportunities, within communities, while simultaneously promoting the sustained protection of the natural environment. Environmental
Education for Sustainable Development can provide basic information related to the environment and sustainable development, thereby equipping people with the tools to participate in decision-making and action.

- Human \& Environmental Health: The health and sustained well-being of the human race is dependent on a healthy environment. Health-related environmental issues include the control and monitoring of pollutants in air, water and soil; good waste management; ensuring safe supplies of food and water; curtailing the proliferation of vectors of disease; as well as programs to curb or control unsustainable use of non-renewable resources and protect bio-diversity - which may have future health implications. Environmental Education for Sustainable Development can promote awareness of links between human and environmental health, provide relevant skills and encourage positive attitudes and action which reduce environmental risks to human health.

- Human Settlements: Intense competition for land, fuelled by population growth and business expansion, has led to human settlements plagued with persistent problems. Major problems are in urban areas, which host most of Jamaica's 2.5 million people. Problems include urban sprawl, unplanned development, inefficient use of space, urban blight, scattered development, housing shortages, increased shortage of land, lack of employment opportunities and disparity in the provision of facilities and amenities. Poverty, economic marginalization and the rural-urban drift result in squatting and unplanned developments. The population is expected to increase to 3 million by the year 2000 , with $60 \%$ projected to be urban. Environmental Education for Sustainable Development can promote healthy communities, green spaces, delivery of sustainable urban infrastructure and services, among planners and officials; and citizen participation in decisionmaking related to the delivery of municipal services. The trend to increasing urbanization suggests that future Environmental Education for Sustainable Development will need to focus significantly on urban issues, conditions and solutions.

- Consumerism: Informed consumers have the power to demand environmentally-friendly products, through their purchasing decisions; and the capacity to influence a range of factors including air pollution, waste generation and management, and energy conservation, through lifestyle decisions. Environmental Education for Sustainable Development can develop informed consumers from an early age, with information on the consequences of consumption choices and the impact of particular products; thereby providing 
individuals and households with the basic for environmentally informed choices. Re-use, recycling and other waste management options can be promoted.

- Cultural Heritage: Cultural heritage is recognized in the Vision Framework as being integral to promoting self-esteem and respect for country. Jamaicans, who are well grounded in and respectful of their culture, including their history, have a context for assessing their current realities and making choices for the future. Environmental Education for Sustainable Development can take advantage of learning opportunities offered by culture, heritage, the use of oral traditions and traditional knowledge systems. It can also assess traditional knowledge and practices, and reemphasize those which are sustainable and which show potential for wider application or development.

- Pollution - Air, Land \& Water: Deteriorating air quality in the major urban centres, mainly due to industrial and vehicular emissions and the burning of municipal and domestic garbage, cause concern. There are also wide-spread air quality issues in rural areas due to farming practices such as the burning of sugar cane. Water pollution is also an increasing problem, due to the contamination of water supply sources and connected downstream wetland, estuary and marine ecosystems, by sediments, pathogens and chemicals - most of them resulting from deforestation of watersheds, improper disposal of wastes, and run-off contaminated by agro-chemicals. Inadequate urban planning contributes to the problem, which has consequences for human health, and bio-diversity. Land pollution is associated mainly with agricultural and industrial misuse. Environmental Education for Sustainable Development can improve citizen and commercial/industrial sector awareness of the risks to human health and safety, to economic sustainability and to the natural environmental posed by unsustainable commercial and industrial activity; leading to changed attitudes and relevant action.

- River Systems: River systems are not listed by JANEAP, but are included here because of their links to multiple ecosystems. Many rivers rise in Jamaica's mountainous hinterland and flow through a range of ecosystems, to the sea. Because they cut pathways and because they provide water for consumption and irrigation, they attract human settlement. They also carry silt from degraded watersheds as well as a range of pollutants generated by human activity, into downstream ecosystems. Rivers can be used as an example of the interactions between ecosystems, humans, and other species: both negative, in terms of the effects of upstream pollution and degradation; and positive, in terms of the impact of river management and the possibilities for recreation and leisure. Target groups include government, resource users, riverside communities and the general public.

- National Parks, Protected Areas and Wildlife: Jamaica's rich natural heritage combines scenic beauty with a variety of ecosystems including wet and dry forests, rivers, caves, mineral springs, sandy beaches, rocky shores, mangroves, herbaceous swamps, swamp forests, salinas, mountains and plains. The island also has a high level of endemism. The biological diversity of the island's terrestrial and marine ecosystems has been affected, in recent years, by deforestation and soil loss, soil and water pollution due to improper disposal of wastes, poorly planned urban developments, and wildlife harvests in excess of ecosystem carrying capacity. Problems of persistent poverty and limited public awareness impact on the integrity of land-based systems. Environmental Education for Sustainable Development activities promote pride in and value for the local ecology and biological diversity, and a sense of environmental stewardship, among natural resource users and the general public. This includes support for the development and management of national parks and protected areas. These activities can also promote sustainable resource management among resource users and government officials, enhance knowledge of and respect for sustainable traditional practices and remedies, and highlight the benefits of outdoor recreation and leisure activities.

- Global Issues: Jamaica's actions form only one small part of the global environmental and sustainability equation. Yet Jamaica, as a tropical island-state, is vitally affected by many global issues, including the degradation of the ozone layer, global warming, the possibility of consequent sea level rise, and marine pollution. Environmental Education for Sustainable Development knowledge outcomes emphasize the inter-relationship of the local and global, and can increase awareness of the existing and potential impact of global environmental challenges on Jamaica's ecosystem.

- Sustainable Tourism: Sustainable tourism is defined as the optimal use of natural and cultural resources for both national development and visitor enjoyment, taking ecology, history and tradition into account. Environmental Education for Sustainable Development can promote awareness and appreciation of local culture - both traditional and current, and responsible enjoyment of the natural environment by Jamaicans and visitors; pointing out the social and economic benefits to be gained. Growing awareness of environmental issues, internationally, also offers new local business 
opportunities in eco-tourism.

- Sustainable Agriculture: Sustainable agriculture relates to the use of methods and products which are environmentally-friendly both on-site and downstream, and which naturally enhance the capacity of the land to keep on producing in the long term. A related area is the sustainable management of fish and other marine resources. Promotion of sustainable agriculture practices has positive implications for health and safety, including the issues of watershed management, water and land pollution; as well as livelihood issues for resource users. The marketing possibilities of organic and 'green' products can be explored.

- Land Use Management: Population growth, coupled with industrial and commercial expansion has resulted in intense competition for land, which is often not allocated to its optimum use. National Physical Plans have not been implemented. The promulgated National Land Policy,1996, seeks to address this situation. Environmental Education for Sustainable Development can promote knowledge of land ecology, and awareness of the importance of sustainable land use planning and practices, among planners, local government officials, developers, resource users and citizens.

- Forestry, Agriculture \& Watershed Management: Woodlands, mostly ruinate or second growth, cover some 45 percent of the country, most of them in rugged terrain or dry, hilly uplands with poor access, therefore limited prospects for industry. Extensive cutting for fuelwood and charcoal manufacture, as well as production of sticks and posts, have caused environmental damage, particularly related to watershed degradation. Watersheds have also been affected by the clearing of steep, unstable slopes for squatting and cultivation. Nineteen of Jamaica's Watershed Management Units are considered critically degraded and in need of urgent remedial work. Agro-forestry and land use control are considered priorities. Environmental Education for Sustainable Development can promote eco-tourism, sustainable agriculture, new production based on traditional local plants, and forestry management information and practices; focusing on natural resource users, communities and students.

- Waste Management: Many urban and rural households lack satisfactory sanitation. In addition, the collection and disposal of solid waste presents environmental, public health, social and liability problems. Special wastes are also an issue. National average sewage generation is over 455 million litres daily, with some 50 percent coming from the major urban centres where treatment facilities are inadequate. Ship-generated waste, particularly from cruise ships, is a concern. The International
Convention on the Prevention of Pollution from Ships (MARPOL) requires that home ports have port reception facilities to treat and dispose of wastes. Environmental Education for Sustainable Development can promote a focus on natural resource stewardship and regeneration, involving learners in clean-ups as well as in actions related to lifestyle values and choices. Specific messages can relate to reduction, re-use and recycling of waste, and the promotion of related household and commercial activities. Partnership opportunities already exist with NGOs working with schools and in some communities; and private sector efforts to promote recycling and bottle collection in schools.

- Coastal \& Marine Resources Management: Jamaica's varied and irregular coastline, which gives rise to a range of coastal features, are affected by large populations residing on the coastal plains, and consequent high levels of economic activity. Numerous sandy beaches and cays, on which the island's tourism industry relies heavily, are under threat from pollution, erosion and illegal sand mining. Wetlands, which act as nurseries for fish and wildlife, and stem coastal erosion, are steadily decreasing. Coral reefs, vital to the tourism and fishing industries and also to protect against coastal erosion, are extensively degraded. In addition there is serious over-fishing. Coastal and marine degradation could affect the tourist industry, with visitors increasingly seeking environmentally friendly destinations. Environmental Education for Sustainable Development can promote awareness on marine ecosystems and issues, and activities which bring positive action on coral reefs, marine ecosystems, sustainable fisheries and tourism. Specific audiences include fishermen and others who earn their living from fishing, watersport activity operators, hotels and citizens in coastal communities.

- Greening of Government-Public Sector: The capacity development of public sector agencies which have environmental roles has begun to receive attention. In addition, there is potential to encourage the development of environmentallyfriendly policies and programs within the public sector, and the setting of 'green' standards for suppliers of products and services to the public sector. Environmental Education for Sustainable Development can promote government's responsibility to set an example in providing environmentally-friendly services, and demanding 'green' standards from their suppliers.

- Clean Technologies: There is increasing attention to practices and technologies which reduce the generation of pollutants, thereby reducing clean-up costs, lessening environmental impact and natural resource depletion, and protecting human health. 
This is achieved through improved technology, better products design, improved processing and product efficiency, or a combination of all three. Environmental Education for Sustainable Development can promote government and private sector responsibility to adopt environment-friendly technologies, raw materials and products, entrench good housekeeping practices in industry, and reuse and recycle waste.

$\circ$ Environmental Economics and Management: Efforts to integrate environmental concerns with economic management are underway. The Natural Resource Conservation Authority has been developing standards for air and water quality and incorporating the "polluter pays principle". The Planning Institute of Jamaica has been analyzing the potential for using environmental economic tools for environmental management and sustainable development in Jamaica. Environmental Economic Policy Instruments (EEPI) are felt to have particular relevance and application in natural resource based economies like Jamaica where aspects of the production process may actually damage the eco-resource base; and where interactions between a range of econo-ecological resources such as forests, marine areas, agricultural areas, may take place within small spaces, with multiple possibilities for disruption. One element being considered for implementation is the System of Environmental and Economic Accounting (SEEA), under which development is measured and monitored by having social and environmental costs factored into project proposals. The system has implications for both the public and private sectors. Sustainable resource management, the minimizing of pollution and the economic and social responsibility of resource users are all focus areas for Environmental Education for Sustainable Development. There is scope to develop partnerships with public utility companies which have responsibility for energy, water and waste, to promote responsible consumption and management, to suggest actions which the general public, or specific resource users, can take and urge the creation of effective incentives.

\section{Emerging Educational Policy Directions}

- School-based Planning: The Ministry of Education and Culture (MOEC) is committed to encouraging increased school-based planning, beginning with the preparation of school mission statements. These will serve as yardsticks for identifying necessary change and assessing the effectiveness of strategies. The focus will be on student achievement.
- Community Involvement: The Ministry has broadened the base of educational planning and implementation, to include input from a range of Jamaicans, through the multi-sectoral National Council on Education. Within local communities, citizens are encouraged to help and protect their schools.

- Curriculum Planning: This includes input from 'stakeholders' who supply information and may negotiate with the Ministry on content they would like infused into curricula - a relationship which began informally in the 1970s and has since been institutionalized. Often, the process seeks to strengthen topics already in the particular curriculum. Stakeholders, including government agencies and NGOs, may also assist with instructional materials and/or teacher education.

- Equity: Inequities arise because Jamaica's multiplicity of secondary institutions vary in respect of curriculum taught, per capita recurrent expenditure, teacher qualifications, physical conditions, and social currency of the final examinations given at different levels of the system. The government has stated its commitment to removing these inequities. The current Reform of Secondary Education (ROSE) programme is designing and implementing a common curriculum for all students in Grades 7-9. The challenge posed by differing levels of student performance is being addressed by variety in instructional materials and teachers' strategies.

- Quality Education for Increased Productivity: The ROSE program seeks to provide quality education, developing productive citizens ready for further education or the working world. ROSE focuses on science \& technology, career development, studentcentred strategies in the teaching-learning process, and restructured student assessment. The success of this thrust at the secondary level rests on the success of the primary level program, where Grade 6 graduates must have acquired literacy, numeracy, learning and social skills. There is increasing emphasis on integrating the social skills aspects of the primary curricula, on the basis that a holistic approach is more likely to promote learning than separate disciplines.

- Finance: Cost sharing, whereby parents pay annual fees to help educate their children at secondary level; and the 'adoption' of schools by business firms, are two approaches to the ever-increasing needs of the education system.

- Teacher Professional Development: The MOEC Tertiary Unit is moving to require that teachers regularly upgrade their professional skills as a prerequisite for promotion in the system; that courses in adult education are offered to all persons teaching at the tertiary level; and that teacher 
educators are involved in curriculum change and receive training relevant to their role in the change process.

\section{Emerging Educational Policy Directions}

- School-based Planning: The MOEC is committed to encouraging increased school-based planning, beginning with the preparation of school mission statements. These will serve as yardsticks for identifying necessary change and assessing the effectiveness of strategies. The focus will be on student achievement.

- Community Involvement: The Ministry has broadened the base of educational planning and implementation, to include input from a range of Jamaicans, through the multi-sectoral National Council on Education. Within local communities, citizens are encouraged to help and protect their schools.

- Curriculum Planning: This includes input from 'stakeholders' who supply information and may negotiate with the Ministry on content they would like infused into curricula - a relationship which began informally in the 1970s and has since been institutionalized. Often, the process seeks to strengthen topics already in the particular curriculum. Stakeholders, including government agencies and NGOs, may also assist with instructional materials and/or teacher education.

- Equity: Inequities arise because Jamaica's multiplicity of secondary institutions vary in respect of curriculum taught, per capita recurrent expenditure, teacher qualifications, physical conditions, and social currency of the final examinations given at different levels of the system. The government has stated its commitment to removing these inequities. The current Reform of Secondary Education (ROSE) programme is designing and implementing a common curriculum for all students in Grades 7-9. The challenge posed by differing levels of student performance is being addressed by variety in instructional materials and teachers' strategies.

- Quality Education for Increased Productivity: The ROSE programme seeks to provide quality education, developing productive citizens ready for further education or the working world. ROSE focuses on science \& technology, career development, student-centred strategies in the teaching-learning process, and restructured student assessment. The success of this thrust at the secondary level rests on the success of the primary level programme, where Grade 6 graduates must have acquired literacy, numeracy, learning and social skills. There is increasing emphasis on integrating the social skills aspects of the primary curricula, on the basis that a holistic approach is more likely to promote learning than separate disciplines.

- Finance: Cost sharing, whereby parents pay annual fees to help educate their children at secondary level; and the 'adoption' of schools by business firms, are two approaches to the ever-increasing needs of the education system.

- Teacher Professional Development: The MOEC Tertiary Unit is moving to require that teachers regularly upgrade their professional skills as a prerequisite for promotion in the system; that courses in adult education are offered to all persons teaching at the tertiary level; and that teacher educators are involved in curriculum change and receive training relevant to their role in the change process.

\section{The Educational System \& Environmental Education}

At all levels of the formal education system, there is some, however, inadequate curricular content in place, on which to base the development of environmental awareness. The primary level curriculum, especially in social studies, seeks to lead children on a journey outward to national and global perspectives, after first establishing a relationship with home, school and community. A recurrent theme how human beings satisfy the need for food, shelter and clothing - introduces the idea of resources, and the effect of culture and climate.

At the secondary level, environmental issues are implied or stated in a variety of disciplines which cover the physical, economic, socio-cultural and political environment of Jamaica, the region and beyond. Environmental education is not, however, a required crosscurricular focus in the current Reform of Secondary Education (ROSE) Project, which seeks to revise the lower secondary curricula and prepare teachers for handling it; although it is included in some subject areas including science and social studies.

Syllabuses of the regional Caribbean Examinations Council (CXC) are the main determinant of what is taught at the upper secondary level. Several of these syllabuses emphasize environmental knowledge and concern and, in their assessment procedures, include measures which seek to tap students' concern. This push is from the top-down, but has some effect on teacher awareness, particularly given the region's psychological orientation towards success in external examinations.

At the tertiary level, the emphasis has largely been on upgrading technical knowledge. Lecturers and tutors must be aware of environmental issues, at least as they affect their particular disciplines. However no interdisciplinary 
measures promote, in the tertiary community as a whole, a real sense of environmental awareness and concern. This despite the fact that some faculties, in particular the University of the West Indies (UWI) School of Education, have been active for over nearly two decades in designing and disseminating resource materials in environmental education.

At all levels, modes of instruction remain overwhelmingly teacher-centred. The environmental awareness of teachers and their students can also be enhanced by sources outside of the formal institutions. These sources include subject associations, learning and resource centres, non-governmental organizations which have school-oriented programs, government agencies, the media, and national and international programs and projects (NEEC, 2010).

\section{Key Agents Delivering Non-Formal Environmental Education for Sustainable Development}

Several agencies presently undertake community-based, non-formal Environmental Education for Sustainable Development programs in specific communities. These include:

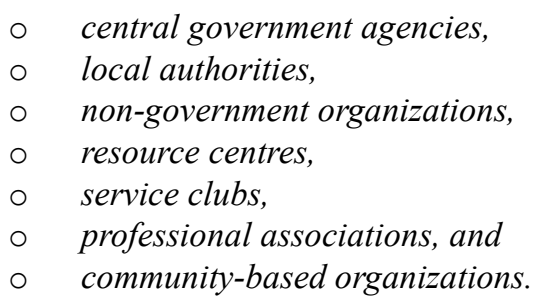

Educational services provided by these agents vary according to their organizational mandates, institutional arrangements, available resources and intended messages and impacts. They disseminate their information in a variety of ways including lectures, seminars, workshops and other public fora, the distribution of brochures and publications and by media messages. Many, particularly within government and the NGO community, link Environmental Education for Sustainable Development activities to environmental and quality of life projects, which provide access to funds, technical assistance and action (NEEC, 2010). The following information categorizes the major groups delivering Environmental Education for Sustainable Development to communities, noting roles and functions:

- Central government agencies carry out Environmental Education for Sustainable Development activities which are linked to policy, with legislative authority; programmes which are national in focus or extend across several parishes. These agencies are generally responsible for approving, planning or implementing infrastructural projects; resource management and control; undertaking social services such as health education, social and community development; or economic planning. Their target audience may be defined broadly as the general public, though many have a particular focus on resource users and local communities. They appreciate, to varying degrees, the need for community involvement in development and planning. Sustainable development is usually an overall goal, by virtue of national policy, but this may not be manifest in agency programmes, approaches and activities.

- Notable among government agencies delivering, promoting and monitoring non-formal environmental education activity is the Natural Resources Conservation Authority (NRCA) - a statutory agency which provides the management framework for conservation, protection and sustainable use of Jamaica's natural resources, in collaboration with partners in the private and public sectors. The organization is committed to providing leadership in environmental policy development; establishment of standards, legislation and regulations; recognition of the set of principles which can inform the country's sustainable development; and working with public sector agencies, private sector companies and nongovernment organizations to fulfill Jamaica's environmental agenda.

- Key concepts and messages contained in NRCA programs targeted to communities relate to the Authority's technical operational areas, namely coastal area management, national parks, protected areas and wildlife management, regulations and compliance, watershed protection and management, pollution control and waste management. The NRCA Public Education, Information and Outreach branch seeks to develop and implement programs to increase public awareness of the need to protect the island's natural resources, facilitate social change, and ensure sound environmental management - the prerequisite for sustainable development.

- Within each parish, NRCA is seeking to have at least one functional NGO addressing sustainable development and environment issues; equipping this entity with the information necessary to promote sound management of the parish resource base.

- Local government authorities have a parish or local community focus, and are backed by legislation governing a range of areas including land use planning and regulation, public cleansing, public health, minor water supply activities, and parochial roads. Local government has major responsibilities regarding environmental management and sustainable community development, and therefore considerable scope to devise innovative means including education - to achieve environmental ends. Local government is currently the subject of 
policy review, and reorganization of institutional and operational structures.

- Non-government and community based organizations which operate in a significant way at the community level, generally have a range of mandates, and may focus on a single subject area, such as conserving birds, or a broad-based area such as sustainable community development or ecosystem management. Most environmental NGOs, and CBOs with environmental mandates, incorporate environmental education activities into their on-going program activities. CBOs are less inclined to do so, but do emphasize participatory and problem-solving skills consistent with the Environmental Education for Sustainable Development Vision Framework. Most NGOs/CBOs seek linkages with other similar groups and with public and private sector partners, in order to gain strength, achieve collective lobbying or share experiences. This is particularly important because most of these organizations are challenged by human and financial resource constraints.

- The private sector has been known to support community-based environmental education initiatives in communities near to their operations. An opportunity exists to more fully involve the private sector in delivering Environmental Education for Sustainable Development at the workplace.

\section{Approaches and Methods}

Four types to community-based environmental education programs may be distinguished, each with its associated approaches and methods. These are:

a) Information dissemination,

b) Community consultation,

c) Community participatory strategies, and

d) Community-based education.

Information dissemination is a one-way mode of transmitting information to communities, using methods such as public service announcements, brochures and exhibitions, and exhibitions. Typically, consultation provides information and seeks limited input from a community, on activities, plans or documents, using methods such as town meetings, panel discussions, open fora and exhibitions. These may be driven by preconceived mandates. Consultation methods which can be used to seek information from communities include focus groups and questionnaires (NEEC, 2010).

Community participatory strategies actively engage people in decision-making related to an entire planning cycle and follow-up action; based on principles of empowerment, equity and democracy. Community-based education related to the environment and sustainable development, engages people in an on-going learning process that focuses on each individual developing the knowledge, skills and values needed to participate in decision-making and action. Community-based educational approaches and methods are many and varied, including popular theatre, community mapping, participatory research, adult/popular education, transformational learning, meetings and workshops.

Many non-formal activities, originating within central government, involve community consultation and information dissemination approaches. CBOs and NGOs are more likely to use community education and community participation approaches.

\section{Target Groups}

The following are some of the groups presently targeted, or strategically placed to effect positive change within communities:

- Resource Users: Persons who use the natural resource base for economic benefit, usually through extractive activity. They include fishermen, farmers, charcoal burners.

- Consumers \& Householders: Persons narrowly concerned with private lives and homes, including issues to do with products purchased, services subscribed to and the manner of managing the home environment.

- Workers: Persons who earn a living in an environment outside the home, and who can often be targeted through trade unions or professional associations.

- Children/Youth: Persons from infants to 25 years, who may be targeted through educational/vocational institutions, youth clubs, church groups or on the streets.

- Women: Defined as a critical group, particularly given their usual responsibility for household hygiene, sanitation and family health care, water collection and storage, waste disposal and fuel collection.

- Young Men: Potentially an important group in community mobilization for environmental management, given that they appear to have spare time and energy.

- Industry: A group covering manufacturing, mining, construction, tourism and commercial activities, to which operating guidelines, standards, competitiveness, raw material availability, waste control and management, and operational efficiency are issues of concern.

- Recreation and Leisure: Persons habitually involved in recreation and leisure activities directly affect and are affected by the natural environment and, as such, have a vested interest in environmental health.

- Legal Community: Given a mandate to uphold the law, the security forces and judiciary are an 
important focus for environmental and sustainable development education.

- Policy Makers: Politicians and local authority members have a direct influence on the communities, and need to be aware of environmental and sustainable development issues so as to take them into account in policy and decision making.

\section{Initiating Responses to Climate Change in Jamaica - Roles and Functions of NEPA and Other Developmental Partners}

Climate change, according to the Meteorological Service of Jamaica (Met Office), is the irreversible change from what is normal or changes in long-term trends in the average climate over time, such as alterations in average temperatures of rainfall. The Met Office is the focal point for climate change issues in Jamaica. The National Environment and Planning Agency (NEPA), has embarked on several partnership initiatives aimed at addressing the problem, including working closely with the Met Office. This is part of NEPA's regulatory responsibilities which are aimed at managing and protecting Jamaica's land, wood and water (NEEC, 2010).

Some of the initiatives to address climate change include: carefully examining the regulatory functions surrounding this issue, as well as mainstreaming climate change considerations into policies, standards and regulations such as Development Orders and guidelines. Additionally, the development applications process provides many opportunities to ensure Climate Change mitigation or adaptation, through the legal requirements imposed on developers. This is supported by the Environmental Impact Assessment (EIA) procedures and public consultations that are a key part of that process.

In recent years, the NEPA has also moved to integrate climate change and hazard mitigation into the EIA process. This is in tandem with growing regional trends. A key component of these initiatives is education and awareness. NEPA provides information on the state of the environment thereby enabling policy makers to properly inform economic, social and educational policies for Jamaica.

The NEPA supports a number of activities which have focused on climate change, its impacts as well as adaptation strategies. Public awareness around climate change issues involving participation in various exhibitions and seminars, as well as raising awareness with key stakeholders are central to this strategy. In partnership with the Canadian International Development Agency (CIDA), the NEPA through the Environment Action Program (ENACT), conducted training in Environmental Stewardship for officers of the Ministry of Education and other target groups, focusing on energy conservation, global warming and climate change issues.

Efforts were also made to integrate climate change into the curriculum framework. It is a theme in the framework aimed at integrating environmental education into the curriculum of the Ministry of Education. That program supports the inclusion of Climate Change adaptation as a key part of the focus for the courses which are also related to environment and sustainable development. The Management Institute for National Development (MIND) offers some of these courses to members of the public as well as Government workers. Web access to Climate Change information is also available on NEPA's website: http://www.nepa.gov.jm.

"A National Climate Change Communication Strategy" is another such initiative. It is a project conducted through the United Nations Development Program (UNDP) and will be implemented over a two-year period by the National Environmental Education Committee - the NEEC which is associated with NEPA. PANOS Caribbean, a non-profit NGO, and other agencies will also partner in the effort. The Environmental Foundation of Jamaica (EFJ) and the MET Office are two of the other partners.

The "Voices for Climate Change" aims to educate Jamaicans on climate change issues, especially adaptation strategies that will reduce the economic and social impacts of climate change on the country. The project targets 'grass roots' people, sector leaders, and the community of popular artists. A strategic part of 'Voices' will be the use of popular artists to reach large sectors that would not otherwise relate or respond to traditional media.

The Ministry of Tourism and its partners also hosted the 'Climate Change Seminar and Exhibition', at the Ritz Carlton Hotel in Montego Bay, in commemoration of World Tourism Day, which is observed on September 27, annually. The seminar which was entitled 'Climate Change and the Bottom Line... The Strategic Business Outlook for the Tourism Sector in Jamaica' was held on September 26, 2008. It was hailed as a major achievement in spreading information about climate change issues to this key target group.

The Air quality Regulations promulgated in 2006 also addresses climate change, through air emissions from the industrial sector and includes the pollutant load from the burning of petroleum based fuels. The Regulations involve the "polluter pays" principle to help control green house gas emissions. During the financial year 2009-10, the NEPA will be reviewing and proposing revised set back limits (from the coastline and from flood prone areas) in the context of a national framework to inform planning and policy decisions, having regard to future climate change scenarios, particularly sea level rise.

The Sustainable Development Network Program (SDNP) is a global catalytic initiative launched by the United Nations Development Program (UNDP) in response to Agenda 21, which articulated the need for improved information dissemination to support sustainable development. The program is geared towards facilitating 
communication between users and suppliers of sustainable development information in developing countries.

Furthermore, the Environmental Foundation of Jamaica (EFJ) is another agency involved in promoting environmental sustainable development initiatives in Jamaica. The EFJ is an independent Foundation which uses the proceeds from a creative debt-swap arrangement to promote sustainable development. This is done mainly through support to projects which address issues of "environmental and child development". Civil society organizations including non-governmental organizations, community-based organizations, and academic institutions are eligible for support. The Foundation promotes, supports and implements activities designed to conserve the natural resources and the environment of Jamaica and foster the well-being of children. To this end, the Foundation aims to give the highest priority to those activities from which benefits are sustainable and/or replicable.

\section{Environment and Sustainable Development Initiatives - Case Study of Jamaica Sustainable Development Network Ltd}

Despite social and financial constraints, Jamaica has been putting in place policies and programs for a sustainable future, which balance economic growth and development, with environment and social justice needs, thus contributing to sustainable development in the years ahead. Ten years after Rio, there have been significant developments in the pace and extent of social, economic and environmental programs, such as those dealing with poverty eradication, local government and public sector reform, land management and watershed protection. The country is also now in a position to measure the changes that are being made to the natural environment. The Government recognizes that there can be no lasting economic development unless the natural resources and services provided by the environment are protected. Integrating environment and development, therefore, is not a luxury but an investment, particularly for small island developing states such as Jamaica (Ministry of Land and Environment, Jamaica, June 2002).

In view of Jamaica's commitment for long - term sustainable development, several agencies (both in governmental and non-governmental sectors) have made efforts in this regards. One such organization is Jamaica Sustainable Development Network Ltd. The Network was established first in 1998 as a UNDP Program and later registered as a not for profit NGO in 2002. Areas of focus of the Jamaica Sustainable Development Network Ltd include:

- The establishment and support of tele-centers in marginalized areas in support of community and personal development.
- Training a range of persons in computer applications, with particular emphasis on those with inadequate opportunity to access these services

- The management of the Liguanea Cybercentre as a model of a competitive, financially viable enterprise providing services to marginalized groups.

- Increasing awareness of the use of ICTs to support sustainable development at the community and national levels

Partnerships and alliances envisage:

- Forging of strategic alliances with public and private sector organizations as well as non government organizations (NGOs) as a mechanism to accomplish its objectives within the constraints of modest resources.

- Establishment of community information networks at the focal points locations (with focus on not only allowing access to information from the Internet, but also function to harness information from community based persons and agencies on current development issues within the respective communities).

Objectives of the Jamaica Sustainable Development Network Ltd include:

- To introduce and connect public, private and nongovernment sector agencies to local and international sources of information on sustainable development utilizing the Internet and other communication tools.

- To develop appropriate information services to support the implementation of local and national development plans.

- To provide information on Jamaica's environment and social and economic development via the Internet to the international community.

Mission of the Jamaica Sustainable Development Network Ltd includes:

o to enhance citizens' capacity to access, understand, distribute and utilize information to enable them to sustain their livelihoods and socio-cultural values while conserving their natural environment.

- citizens actively making use of understandable and relevant information to enhance the quality of life within their communities for present and future generations.

\section{Summing Up}

Environmental education, referred to in Agenda 21 as Environmental Literacy, after the UN Conference in Rio De Janeiro in 1992, has emerged as a vital and critical issue at the global, national and local level as we enter a new 
millennium. In Jamaica, a small island developing state, this issue has been on the agenda since the early 1970s. Many Jamaican institutions, organizations and individuals have been involved in initiatives related to the Environmental Education throughout the country as concern for the quality of the environment and the implications for human health, livelihoods and sustainable prosperity has become progressively deeply rooted in the national consciousness. The growing economic and social challenges facing the nation as we explore the path to sustainable development have helped to set the stage for the evolution of an unprecedented national effort in Environmental Education for citizens to attain sustainable development in the $21^{\text {st }}$ century.

The NEEC (formed in 1993 by the Natural Resources Conservation Authority) focuses specifically on environmental education. Among the government agencies charged with environmental responsibilities are:

a) the Ministry of Health and Environmental Control,

b) the Ministry of Agriculture, and

c) the Natural Resources Conservation Authority.

It is envisaged that the same enthusiasm will evolve from every citizen and organization, as they become more environmentally responsive in every community. It cannot be denied that protecting the environment is a complex issue but as the Jamaican Government seeks to stimulate "economic re-growth", the nation is faced with the challenge of stimulating the minds of people to create an interest in exploring solutions to environmental issues. Jamaica will continue to achieve its goals in adopting the right approach for the ongoing interdependence of the environment and the economy, as it seeks to protect precious natural resources in the 21 st century and beyond.

To sum up, the Government recognizes the essential linkages between environmental policy and industrial policy. Most of the economic activities in Jamaica depend on the use of the country's natural resources. It is, therefore, important to develop mechanisms for sustainable management of the country's natural resources and reduce the negative impact of industrial activities on the environment. In this regard, the key goal of Government policy in all areas is "sustainable economic development".

\section{References}

[1] Clarke S. (2005) "Tertiary Education in a Changing World" in R. Holding and O. Burke" (Eds.), Revisiting Tertiary Education Policy in Jamaica: Towards Personal Gain or Public Good? Ian Randle Publishers, Kingston.

[2] Dalal-Clayton, B. and Bass S. (2000). "National Strategies for Sustainable Development: The Challenge Ahead", International Institute for Environment and Development, UK.

[3] Garitty, M. Picard, L (eds.) (1996). "Policy Reform for Sustainable Development in the Caribbean", IOS Press, Amsterdam.
[4] The Government of Jamaica and the government of the United Kingdom (2002). "Jamaica 2015", Cabinet Office and the Planning Institute of Jamaica, Kingston.

[5] Hopkins C. and McKeon R. (2000). "Education for Sustainable Development: An International Perspective" in D. Tilbury, R, Stevenson, J. Fein and D. Schreuder (eds.) Education and Sustainability: Responding to the Global Challenge, International union for Conservation of Nature and Natural Resources, Gland.

[6] Longworth, N. (1999). "Making Lifelong Learning work: Learning Cities for a Learning Century", Sterling: Kogan.

[7] Munroe T. (1999). "Renewing Democracy into the Millennium", the Press University of the West Indies, Kingston.

[8] Shaeffer, S. (1994). "Participation for Educational Change: A Synthesis of Experience", UNESCO, Paris.

[9] Social Development Commission (1998). "Social Development Commission Corporate Plan 1998-1999”, Social Development Commission.

[10] Stevenson R. (2002). "Education and Sustainable Development: Perspectives and Possibilities" in D. Tilbury, R, Stevenson, J. Fein and D. Schreuder (eds.) Education and Sustainability: Responding to the Global Challenge, International Union for Conservation of Nature and Natural Resources, Gland.

[11] The Commonwealth Foundation and the Association of Development Agencies (1999). "Citizens and Governance: Civil Society in the New Millennium", Kingston.

[12] Tilbury, D. Stevenson, R. Fein, J, Schreuder, D. (eds.) (2002). "Education and Sustainability Responding to the Global Challenge", International Union for Conservation of Nature and Natural Resources, Gland.

[13] United Nations Development Programme, (2000). "Jamaica Human Development Report", Planning Institute of Jamaica, Kingston.

[14] http://pcf4.dec.uwi.edu/viewpaper.php?id=306\&print=1, Accessed on January 4, 2014.

[15] http://www.nrca.org/neecwebsite/actionplan/planbook/table ofcontents.htm, Accessed on January 4, 2014.

[16] http://www.unep.org/training/programmes/undesd.asp, Accessed on January 4, 2014.

[17] http://www.envirolink.org/resource.html?catid=4\&itemid $=6$ 30921160885, Accessed on January 4, 2014.

[18] http://www.dogoodjamaica.org/organizations/environmental _foundation_of_jamaica, Accessed on January 4, 2014.

[19] Ministry of Land and Environment (June, 2002). “Jamaica National Report”, Ministry of Land and Environment Kingston, Jamaica.

[20] http://www.cfa-international.org/NGO\%20directory/DFA498.htm, accessed on January 9, 2014.

[21] http://www.carisnet.org/en/node/19, accessed on January 9, 2014. 
[22] National Environmental Education Committee (NEEC) (2010). "A National Environmental Education action Plan for sustainable Development (1998-2010)”, National Environmental Education Committee (NEEC), Jamaica.

[23] Barrett, Shermaine (2006). "Education for Sustainable Development: A Framework for Jamaica", Education Division, Faculty of Education and Liberal Studies, University of Technology, Jamaica.

[24] Knowledge Management Branch of Division for Public Administration and Development Management (DPADM)/United Nations Department of Economic and Social Affairs (UNDESA) (June, 2003). "Governance World Watch", New York, NY, USA.

[25] United Nations Publication (2007). "Participatory Dialogue: Towards a Stable, Safe and Just Society for All", United
Nations Publication, New York, NY, USA.

[26] End Decade Assessment of World Summit for Children Goals (November, 2010). "End Decade Assessment of World Summit for Children Year 2000 Goals National Report”, End Decade Assessment of World Summit for Children Goals, Jamaica.

[27] UNSESCO (October, 2006). "Education for Sustainable Development Toolkit", Section for Education for Sustainable Development (ED/UNP/ESD), UNSESCO, Paris, France.

[28] Economic Commission for Europe, Committee on Environmental Policy, (October, 2013). "The Environment for Europe mid-term review of the Astana Conference main outcomes: main findings of the review", Economic Commission for Europe, Committee on Environmental Policy, Geneva, Switzerland. 